career by being assistant to the professor of general pathology. In 1894 he was appointed professor of hygiene and director of the Institute of Hygiene at Siena, and during the next few years held corresponding posts at Montevideo (1895-98), Bologna (18981915) and finally at Rome.

Sanarelli's most important work was connected with the pathogenesis of cholera, typhoid fever, and spirochætosis, immunity and ultra-viruses. His name has been attached to the organism which is the cause of myxoma in the rabbit (Sanarellia cuniculi), but the organism which he called Bacillus icteroides and claimed to be the cause of yellow fever was shown by Reed and Carroll to be merely a variety of the swine cholera bacillus. In addition to numerous articles in periodical literature, such as the Centralblatt für Bakteriologie, Comptes rendus de l'Académie des Sciences, Annales de l'Institut Pasteur, etc., he was the author of several books. He was also the editor of the Rivista di Malariologia, which was founded in 1922 under the name of Bolletino Malario. logico. He was the recipient of many honours. $\mathrm{He}$ was made a senator of Italy in 19\&0, and was rector of the University of Rome in 1922-23. He was also an honorary member of many learned societies in Italy and other countries.

J. D. Rolleston.

\section{Mr. F. M. Davis}

Educated at Harrow and at Caius College, Cambridge, Mr. F. M. Davis joined the staff of the Fisheries Department of the Ministry of Agriculture and Fisheries as an assistant naturalist in 1911; at the time of his death at the age of fifty-one he was principal naturalist in charge of the Fisheries Laboratory, Lowestoft.

Davis served in the War of $1914-18$ as a captain in the London Regiment, was wounded, and held prisoner for nearly two years. On his return he spent many months carrying out investigations on trawlers, and he also made a very thorough survey of the fishing gear and methods employed in the maritime fisheries of England and Wales, the results of which are embodied in his well-known paper on the subject, now in its third edition (Fishery Investigations, Series II, 15, No. 2 ; 1936). He took part in an exploratory voyage to Lousy and George Bligh Banks in 1920. His subsequent work included several years investigation of the bottom fauna of the North Sea by means of the Petersen grab, resulting in two papers of great ecological interest, demonstrating inter alia the existence of vast beds of shell. fish (Spisula and Mactra) on the Dogger Bank, which were subject to great fluctuations from year to year.

Thereafter Davis devoted several years to the practical study of the relation between the mesh of the trawl and the size of fish caught, and his results were basic for the internation 1 ( onvention on mesh and size-limits signed in 1937. In the last year or two he became greatly interested in the great cod fisheries in the far north, and made several trips on trawlers to the Bear Island and Spitsbergen grounds. His bent was essentially practical ; he was happiest at sea, and the vast experience there gained made him an acknowledged expert on all practical fishery problems, especially those relating to fishing gear.

Davis was a first-class rifle shot and had many successes at the Bisley meeting, which he attended regularly. His modesty was excessive; only those who knew him well could appreciate the shrewdness of his judgment and the depth of his knowledge, which he was apt to hide under a casual manner. $\mathrm{He}$ was greatly loved by his colleagues and a wide circle of friends.

E. S. Russell.

\section{Mr. Jonathan Hodgkinson}

OXFORD mathematics have suffered three grievous losses in the past few weeks by the deaths of Prof. A. E. H. Love, Mr. Jonathan Hodgkinson and Dr. E. G. C. Poole.

Jonathan Hodgkinson went up to Jesus College from Carlisle Grammar School as mathematical scholar in 1904. He won the University Mathematical Exhibition in 1906, was the Senior Mathematical Scholar in 1910 and obtained two first classes in the school of mathematics. From 1913 until 1921 he was a prize fellow of Merton College, one of the few colleges which retains this traditional reward of learning. During the War of 1914-18 he served in the infantry and with the Tank Corps as a major.

After the War, Hodgkinson became fellow and tutor in mathematics at Jesus College, and was for a time University lecturer in mathematics. He was a great teacher. He got good material with which to work and he made the very best of it. He worked his men hard but they responded, and the record of University honours in mathematics by the Jesus College men of the past twenty years is an impressive one. Although Hodgkinson was primarily a teacher he found time to do original work on the pure mathematics of applied mathematics. He was an authority on hypergeometric functions and published many papers on this and other subjects. For some years he was one of the three editors of the Quarterly Journal of Mathematics, and worked well and ungrudgingly at that difficult task.

In his college Hodgkinson was particularly helpful in matters of finance, where his analytical mind and shrewd commonsense were of value to his colleagues. Like so many of the mathematical and scientific dons in Oxford, he was an efficient administrator, and for some years wisely guided his college in disciplinary matters. During the last (ighteen months his health had failed him, and though there were periods when it seemed that he might recover, at least in part, his health, he died on June 21. He was fifty-four years of age.

We regret to announce the following deaths:

Mr. G. S. Blake, formerly geological adviser to the Palestine Government.

Dr. Alvin S. Wheeler, emeritus professor of organic chemistry in the University of North Carolina, on May 12, aged seventy-three. 